\title{
AN ECONOMIC ANALYSIS OF THE DETERMINANTS OF ENTREPRENEURSHIP: THE CASE OF MASVINGO INFORMAL BUSINESSES
}

\author{
Clainos Chidoko, Researcher \\ Department of Economics, Great Zimbabwe University, Zimbabwe \\ E-mail: cchidoko@gmail.com
}

\begin{abstract}
In the past decade, Zimbabwe has been hit by its worst economic performance since its independence in 1980. Capacity utilization shrank to ten percent and unemployment rate was above eighty percent by 2008 as the private and public sector witnessed massive retrenchments. As a result many people are finding themselves engaging in informal businesses to make ends meet. However not all people have joined the informal sector as has been witnessed by the number of people who left the country in droves to neighbouring countries. It is against this background that this research conducted an economic analysis of the determinants of entrepreneurship in Masvingo urban with an emphasis on the informal businesses. The research targeted a sample of 100 informal businesses (30 from Rujeko Light industrial area, 40 from Mucheke Light industrial area and 30 from Masvingo Central Business District). The businesses included among others flea market operators, furniture manufacturers, suppliers and producers of agricultural products, and food vendors. The research found out that level of education, gender, age, marital status, number of dependants, type of subjects studied at secondary school and vocational training are the main determinants that influence the type of business that entrepreneur ventures into. The study recommends formal training for the participants, for the businesses to continue into existence since they fill in the gap that is left vacant by most formal enterprises.
\end{abstract}

\section{KEY WORDS}

Informal sector; Entrepreneurship; Education level; Employment.

Entrepreneurship is the act of being an innovative in an effort to transform the innovations into economic good. This results in new organizations or may be part of rejuvenating old firms in response to a prevailing economic environment. This entails starting a business venture. In recent years, however, the term has been extended to include social and political forms of entrepreneurial activities.

The term informal sector is commonly used to refer to that section of labour market in the developing countries that has absorbed significant numbers of jobseekers, mostly in selfemployment, and to workers in very small production units (ILO, 2000). Informal activities are often characterized by low levels of capital, skills, access to organized markets and technology; low and unstable incomes and poor and unpredictable working conditions. These activities are often outside the scope of official statistical enumeration and government regulations, and beyond formal systems of labour and social protection (ILO, 2000:20)

Zimbabwe has been hit by its worst economic performance since its independence in 1980. Capacity utilization shrank drastically and unemployment rate rose to $80 \%$ by 2008 as the private and public sector witnessed massive retrenchments. As a result many people are finding themselves engaging in informal businesses to make ends meet. However not all people have joined the informal sector as has been witnessed by the number of people who left the country in numbers to neighbouring countries, especially to South Africa. It is against this background that this research conducted an economic analysis of the determinants of entrepreneurship in Masvingo urban with an emphasis on the informal businesses, that include food venting, flea markets and furniture manufacturers among others.

Informal sector is an important segment of various economies of the world since it plays an important role in economic development. The Asian Tigers went through the same route and today they are a force to reckon with in the world. In Zimbabwe the sector also forms an integral part of the economy and ignoring it is tantamount to committing economic injustices that would see the businesses shrinking to unproductive levels. This would result in poor performance of the economy. 
In this case the research sought to determine those factors that lead entrepreneurs into informal sector businesses and the type of business they end up in, with specific reference to Masvingo urban. Masvingo city is in Masvingo Province in Zimbabwe. It lies in the semi arid to arid region of Zimbabwe where there is limited significant agricultural ventures as compared to other regions like Mashonaland. This leads many inhabitants to engage in informal business besides farming, to make ends meet. As a result there was a proliferation of micro, small and medium enterprises in Masvingo as a result of the economic crisis that hit Zimbabwe in the past decade.

\section{ENTREPRENEURSHIP THEORY}

Participating in a new business creation is a common activity among many people in Zimbabwean workers over the course of their careers. This has been a major driver of economic growth in many African countries. Entrepreneurial activities differ depending on the type of organization and creativity in question. It ranges in scale from sole ventures to major firms creating many job opportunities. Many entrepreneurial ventures seek capital in order to raise money to build the business. Many kinds of organizations now exist to support wouldbe entrepreneurs including specialized government agencies, banks and some nongovernmental organizations.

The understanding of entrepreneurship derive much from the work of economist Joseph Schumpeter, Ludwig von Mises and Friedrich von Hayek. According to Schumpeter, entrepreneurship results in new industries. This goes hand in hand with the notion that entrepreneurship will create new firms. The acts of entrepreneurship are often associated with true uncertainty, particularly when it involves bringing something new to the world, whose market never existed before. The entrepreneur is widely regarded as an integral player in the business world and particularly as an engine for job creation and economic growth.

Traits of an entrepreneur. Many entrepreneurs have same character traits as leaders or managers. Entrepreneurs are often contrasted with managers and administrators who are said to be more methodical and less prone to risk-taking.

Types of Entrepreneurs. Literature has distinguished a number of different types of entrepreneurs, for example; Social: Motivated by a desire to help, improve and transform social and economic conditions. Key traits and characteristics of highly effective social entrepreneurs include ambition and a lack of acceptance of the status quo. Serial: Continuously comes up with new ideas and starts new businesses. Lifestyle: Places passion before gain when starting a new business.

Determinants of Entrepreneurial Activity. Entrepreneurial activity and new firm formation are unquestionably considered to be engines of economic growth and innovation (Baumol, 1990; Murphy et al., 1991) in Mariassunta Giannetti and Andrei Simonov (2004, pp 269-313).

There are various factors that determine or influences one to become an entrepreneur. Lucas (1978) showed that individuals who have higher entrepreneurial productivity start their own firms. Lucas predicts that more productive entrepreneurs run larger firms. Also Evans and Leighton (1989) found out that the probability of switching into self-employment is roughly independent of the total labor market experience. Also, poor wage earners or the unemployed, and individuals who have changed jobs a lot have a higher probability of entering into self employment.

The effect of education on the decision to become an entrepreneur may differ across sectors. A high propensity to take risks is also considered to be an important characteristic of entrepreneurs. Kihlstrom and Laffont (1979) show that, more risk averse individuals are expected to become workers, while the less risk averse become entrepreneurs. Evans and Leighton (1989), also assert that individuals with greater assets are more likely to get into self-employment, ceteris paribus.

Mariassunta Giannetti and Andrei Simonov (2004) assert that government regulations, taxes, and laws may influence one to become an entrepreneur. Also Davidsson et al. (1994) show that the rate of new firm formation depends on market conditions: market size, 
measured by population size and density, and market growth, measured by population and employment growth, have a positive impact on new firm formation.

\section{MATERIALS AND METHODS}

This section describes how the research was carried out. It describes the procedures undertaken during the course of the research design, research instruments, data presentation and analysis plan.

Research Design. A descriptive survey method was used in the research. The research managed to give the economic determinants of entrepreneurship in Masvingo focusing on informal businesses.

McMillan and Schumacher (1958) describe survey design as the existing achievements, attitudes, behaviors and other characteristics of the group of subjects. It helps to describe and clarify factors and variables that determine the entrepreneurship of Masvingo informal business owners. It is more practical as it gives the conditions prevailing at the time of the research. Through questionnaires the respondents provided the push and pull factors that lured them into informal business ventures, and the conditions inherent in them that intrinsically drove them into such businesses.

Subjects. All the informal business owners in Masvingo urban, that included among others flea market operators, furniture manufacturers, suppliers and producers of agricultural products, and food vendors were identified as the target population. A sample of 100 people was given questionnaires.

Sampling procedure. A sample is a subset of the population that displays all the characteristics of the population in order to be truly representative. The sample consisted of 100 people out of informal business owners in Masvingo urban (30 businesses from Rujeko Light industrial area, 40 from Mucheke Light industrial area and 30 from Masvingo Central Business District).

Judgmental and convenience sampling procedure was employed based on personal experience and judgment. According to Cohen and Marion (1994: 89) purposive sampling is when the researcher handpicks the cases to be included in the sample on the basis of their judgement.

Research instruments: The researchers used questionnaires to collect data. The instrument sought to get from informal business people the economic attributes that made them enter into informal business activities.

Data Collection Procedure. The researcher personally distributed questionnaires and collected them from respondents. Once all the questionnaires had been retrieved, information was processed so that generalizations could be arrived at.

\section{ANALYSIS AND DISCUSSION OF RESULTS}

This section is devoted to the presentation, interpretation, analysis and discussion of the findings that came out of the research that was conducted on the Economic Analysis of the Determinants of Entrepreneurship: The Case of Masvingo Informal Businesses.

Background Information. The research captured gender, age, level of education, type of subjects studied at secondary school, vocational training, marital status and dependants of informal business owners in Masvingo urban.

Analysis. It could be deduced that the majority of the informal business people are female. However more males are more into production enterprises, while females are more into retailing and venting. Eighty- five percent of the respondents are in the 20-45 year age groups. This could be so since informal trading and business operations need more energy, and these age groups are the more economically active. The more aged female groups are into food venting, selling cooked food, fresh cabbages, tomatoes, onions, and other farm produce; and some other artefacts, while their counter-parts are into production of wood and steel products such as furniture and building material such as door and window frames. This line of business needs experience, which the aged have acquired over the years. 
Ninety percent of the respondents have never gone beyond Grade Seven, while five percent went up to 2 years into secondary school. Three percent have gone up to Form 4 , but have failed to acquire 5 ordinary level passes. Two percent of the respondents have gone through vocational training at Polytechnic colleges. A glance at the educational levels, shows us that the less the number of years in school, the more one is likely to enter into self employment. For those who went into secondary school, eighty-three percent studied commercial and/or practical subjects at one point, while the remainder studied neither of those subjects.

Ninety-two percent of the respondents are married. The widowed, divorced or separated were classified as married since most of them got into such categories when already in business. The unmarried are mostly into retailing and these are mostly into flea market business. These are mostly young ladies in the 20 to 35 age groups. The other significant category is made up by young ladies and boys who are into airtime venting. Most of them also fall into the same age groups.

The number of dependants among the respondents vary significantly. Most of them have dependents ranging from two to ten, depending on whether one also takes care of the young and /or aged back home in the rural areas.

Discussion. The research has revealed that many people enter into informal businesses asa result of lack of the necessary skills needed for formal sector employment. The characteristics displayed show that most of these informal business owners in Masvingo urban have not spent significant number of years in school, as a result they do not have formal training that can be harnessed by the formal sector. Age and gender also play a significant role in the type of enterprise one engage in. From the analysis it seems marital status and number of dependants do not influence much on the type of business one engages in, or whether it influences one to engage in informal business. Overally, education level has much bearing on whether one finds him/herself in informal business venture.

\section{CONCLUSION AND POLICY RECOMMENDATIONS}

The research has found out that gender, age, level of education, type of subjects studied at secondary school, vocational training, marital status and number of dependants have influence on determining entrepreneurship of informal business owners in Masvingo urban. However, the level of education attained and training have more impact on determining whether one will find him/herself in self employment or not, and also the type of business one ventures into.

Informal businesses bridge the gap of products that may not be found on the formal market. They also provide employment to those who may not be absorbed by the formal enterprises. In most countries these businesses have contributed significantly to Gross Domestic Product, although their activities cannot be captured in the national statistics. In this case, considering this significance, the study recommends formal training for the participants, for the businesses to continue into existence since they fill in the gap that is left vacant by most formal enterprises. The government in collaboration with Masvingo City Council and interested non- governmental organisations can come together and champion this cause so as solidify the foundations of the informal businesses in Masvingo urban to make them strong firms and eventually graduate into formal businesses. This is healthy for the business owners and the economy as a whole.

\section{REFERENCES}

[1] Audretsch, D.B., I. Grilo and A.R. Thurik, 2007a, Handbook of Entrepreneurship Policy,Cheltenham, UK and Brookfield, US: Edward Elgar Publishing, forthcoming.

[2] Audretsch, D.B., I. Grilo and A.R. Thurik, 2007b, Explaining entrepreneurship and the role of policy: a framework, in: D.B. Audretsch, I. Grilo and A.R. Thurik (eds), Handbook of Entrepreneurship Policy, Cheltenham, UK and Brookfield, US: Edward Elgar Publishing, forthcoming. 
[3] Blau, D., 1987, A time-series analysis of self-employment in the United States, Journal of Political Economy 95(3), 445-467.

[4] Davidsson, P., 2004. Researching Entrepreneurship. International Studies in Entrepreneurship, Boston,USA

[5] Evans, D.S. and B. Jovanovic, 1989, An estimated model of entrepreneurial choice under liquidity constraints, Journal of Political Economy, 97(4)

[6] Holmes, Th.J. and J.A. Schmitz Jr., 1990, A theory of entrepreneurship and its application to the study of business transfers, Journal of Political Economy, 98(2)

[7] Lucas, R., 1978, On the size distribution of business firms, Bell Journal of Economics 9(3).

[8] Mariassunta Giannetti and Andrei Simonov, Swedish Economic Policy Review 11 (2004) 269-313. 